日臨外会誌 $80 （ 4) ， 798-803 ， 2019$

症例

\title{
腹膜炎で発症し保存的に救命した劇症型 $\mathrm{A}$ 群溶血性連鎖球菌感染症の 1 例
}

関東中央病院外科

岩下幸平小林敦夫高田厚河原正樹

症例は39歳, 女性. 前日からの腹痛と発熱, 水溶性下痢を主訴に来院. 著明な腹膜刺 激症状と炎症反応異常高值を認め, 急性汎発性腹膜炎と診断した. 画像検査では, 消化 管穿孔や腸管虚血などの所見は認めず，上記症状の原因として原発性腹膜炎を疑った. 厳密な循環・呼吸管理, 広域抗菌薬, カテコラミン, 持続的血液滤過透析 (以下 CHDF）とエンドトキシン吸着療法（以下 PMX-DHP）を併用した集中治療を開始した. 第 4 病日の血液培養にて $\mathrm{A}$ 群溶連菌が検出され, 劇症型溶連菌感染症による原発性腹 膜炎と診断した. 外科的治療の必要性を考慮しつつ厳重な観察下に上記治療を行ったが, その後全身状態は徐々に改善し, 第23病日に退院となった。劇症型溶連菌感染症による 原発性腹膜炎は稀な疾患であるが, 大半の症例において開腹洗浄ドレナージなど外科的 治療が施行されており, 保存的治療による救命例の報告はない. 若干の文献的考察を交 えて報告する．

索引用語：STSS, 原発性腹膜炎, 保存的治療

緒言

劇症型溶連菌感染症 (Streptococcal Toxic Shock Syndrome：以下STSS）は, 咽頭炎などの局所感染 から, 肺や筋膜, 子宮付属器など全身のあらゆる蔵器 に突発的に発症し，急速に多臓器不全へと至る敗血症 性ショックの病態である. STSSは1992年に本邦で最 初の典型的症例が確認されてから年間100 200人が罹 患しており，致命率は約 $35 \%$ と非常に予後不良な疾患 である. STSSの罹患部位, 症状は多彩であるが, 原 発性腹膜炎を呈する症例は $1 \%$ 程度と極めて稀であ る.さらに, 原発性腹膜炎の感染経路は不明であるこ とが多く, 特徵的な臨床所見や画像所見にそしいこと もあり，その診断は極めて困難である ${ }^{122)}$. 原発性腹 膜炎を発症するSTSSにおいて，感染経路や治療法に ついての考察は少ないが, 多くの症例では診断的治療 として外科的ドレナージが行われている. 今回われわ れは, 原発性腹膜炎の病態を呈したSTSSに対し，保 存的治療のみで救命しえた症例を経験したので報告す る.

2018年12月27日受付 2019年 1 月28日採用

〈所属施設住所〉

†158-8531 東京都世田谷区上用賀 6-25-1

\section{症例}

症例 : 39歳, 女性.

主訴 : 発熱, 腹痛, 下痢.

既往歴/手術歴：なし.

内服歴：なし.

家族歴：特記事項なし.

現病歴：来院前日から下腹部の間歇痛と 10 行/日の 水様性下痢が出現. 徐々に腹痛が増悪するとともに, $39.2^{\circ} \mathrm{C}$ の発熱を認め, 当院内科へ外来受診となった. 著明な腹膜刺激症状を認め, 血液検査にて CRPの異 常高值（33.9mg/dL）を認めたため, 消化管穿孔の疑 いで外科紹介となった。

来院時現症：意識清明，体温38.7度，血圧69/46 $\mathrm{mmHg}$, 脈拍 125 回/分, 整. SPO2 100\% (room). 腹 部は膨隆し全体に圧痛, 反跳痛および筋性防御を認め た. 腸蠕動音は減弱.

血液検査所見：WBC 19,000/ $\mu \mathrm{L}(\mathrm{Neu} 52 \%), \mathrm{RBC}$ $484 \times 10^{4} / \mu \mathrm{L}, \quad$ Hb $8.9 \mathrm{~g} / \mathrm{dL}, \quad$ Plt $19.8 \times 10^{4} / \mu \mathrm{L}, \quad \mathrm{T}$-bil $0.6 \mathrm{mg} / \mathrm{dL}, \quad$ AST $25 \mathrm{IU} / \mathrm{L}, \quad \mathrm{ALT} 13 \mathrm{IU} / 1, \quad$ BUN $37 \mathrm{mg} /$ $\mathrm{dL}, \quad$ Cr $1.81 \mathrm{mg} / \mathrm{dL}$, CK 70IU/L, CRP $33.9 \mathrm{mg} / \mathrm{dL}$, PT-INR 1.17, APTT 37.8秒, FDP $165 \mu \mathrm{g} / \mathrm{mL}$, ATIII $92 \%$, エンドトキシン除性, プロカルシトニン 100 以下. 

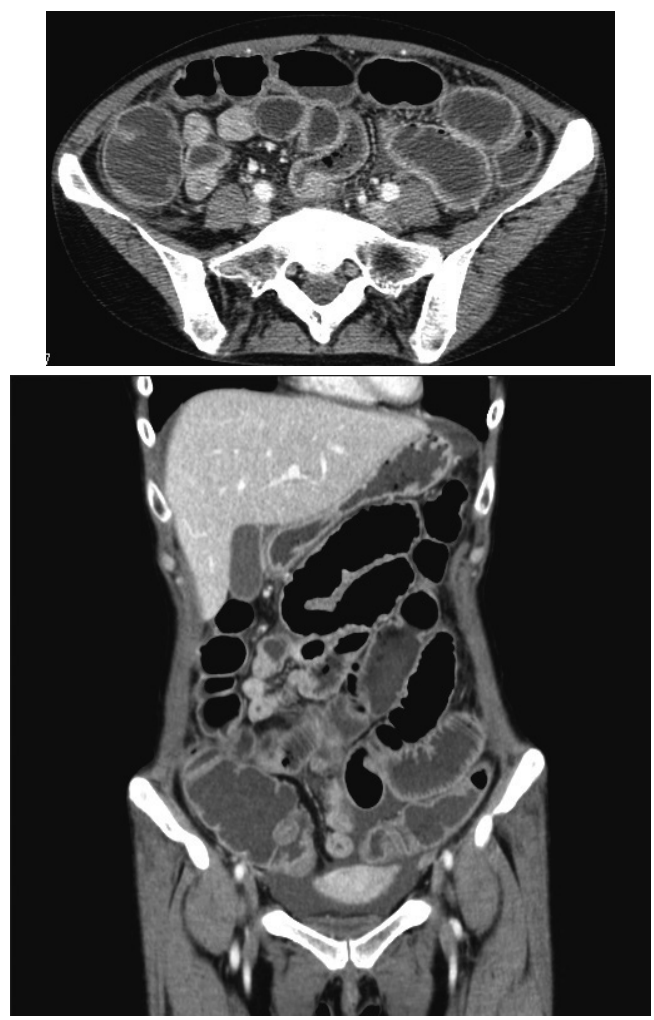

Fig. 1 腹部造影 CT（ $\mathrm{a}$ ：水平断, $\mathrm{b}$ ：冠状断） $\frac{\mathrm{a}}{\mathrm{b}}$

血液ガス : pH 7.40, $\mathrm{PaO} 2127 \mathrm{mmHg}$ (room air), PCO2 26.3mmHg, HCO3- 18.1 mmol/L, BE -4.1 $\mathrm{mmol} / \mathrm{L}$, lactate $0.8 \mathrm{mmol} / \mathrm{L}$, 急性期 DIC score 4 点, SOFA score 3 点.

炎症反応の異常高值と腎機能障害, 播種性血管内凝 固症候群（以下 DIC）, 軽度の代謝性アシドーシスを 認めた。

腹部単純 $\mathrm{X}$ 線検査 : 小腸拡張像およびニボー像を認 めた。

腹部造影 CT 検査 : 小腸全体の著明な拡張と小腸壁 の浮腫状壁肥厚を認めたが, 小腸閉塞や腸管虚血, お よび消化管穿孔などを示唆する所見は認めなかった. 骨盤内腹膜の肥厚およびDouglas 窩に少量の腹水貯留を 認めた. 子宮付属器の異常所見は認めなかった(Fig. 1).

来院後経過：身体所見・血液検査所見とあわせて, 敗血症および急性汎発性腹膜炎, DIC と診断した. 緊 急手術も考慮したが, 造影 CTにて消化管穿孔, 腸管 虚血などによる病態は否定的であり，代謝性アシドー シス, 末梢循環不全のいずれも軽度であったこと,
SOFA スコアも軽症範囲内であったこと，などから集 中治療室（以下 ICU）にて集学的治療を開始し, 厳重 に経過観察の方針とした。

Fig. 2にICU入室後の収縮期血圧と CRP, 乳酸值の 継時的変化を示す. ICU入室時, 低血圧に対しノルア ドレナリンを $0.038 \mu \mathrm{g} / \mathrm{kg} / \mathrm{min}$ で開始した．血清乳酸 值を指標に過剰輸液とならないように配慮しつつ, 細 胞外液として晶質液とアルブミン製剂を $40 ８ 0 \mathrm{ml} / \mathrm{hr}$ の輸液速度で投与した．高サイトカイン血症，急性腎 障害に対して右大腿静脈に血管アクセスを確保し, CHDF (polymethylmethacrylate膜(以下 PMMA 膜), Hemofeel ${ }^{\circledR} \mathrm{CH}-1.8$, 東レ・メディカル, 血液流量 100 $\mathrm{ml} / \mathrm{min}$, 透析液流量 $500 \mathrm{ml} / \mathrm{hr}$, 濾液流量 $300 \mathrm{ml} / \mathrm{hr}$ ) と PMX-DHPを直列回路で使用した。抗菌薬はドリ ペネム $1.5 \mathrm{~g} /$ day を入院後ただちに開始し，ガンマグロ ブリン $5 \mathrm{~g}$ を 3 日間投与した. DICに対してはトロン ボモジュリン16,640U/dayを 5 日間投与した. 当初, 昇圧剂使用にもかかわらず循環動態は不安定であった が, CHDFと PMX-DHPの開始後速やかに血圧は上 昇し循環動態は安定したため, ノルアドレナリン投与 は約 24 時間で終了とした. 尿量は $0.5 \mathrm{ml} / \mathrm{kg} / \mathrm{hr}$ 以上と 安定しており，血清乳酸值の上昇も認めなかった。第 3 病日に血管アクセスカテーテルを抜去し，第 4 病日 にICU退室となった。入院時に採取した血液培養か らStreptococcus pyogenesが検出され, A群溶連菌 (GroupA Streptococcus Pyogenes : 以下GAS) による 原発性腹膜炎およびSTSS と診断した。外科的治療を 行うことなく全身状態は改善し, 急性腎障害・DICか ら離脱した。第 8 病日から経口摂取も可能となり, 大 きな合併症なく第23病日に退院となった.

\section{考察}

GASは口腔内常在菌として知られていたが，1980 年代中頃から各国でGASによるSTSSの報告例が急 増している. GASによるSTSSは, 症状の進行が急激 であることが特徴的であり，発病から数十時間以内に ショック症状, 多臓器不全, 急性呼吸窮迫症候群など を伴う致命率の高い疾患である．我が国では 5 類感染 症 (全数把握) に指定されており, 診断後 7 日以内に 届け出が義務付けられている．2006年に届け出基準が 変更され, 現在はショック症状に加えて肝不全, 腎不 全, DIC, 軟部組織炎などのうち 2 つ以上を伴う $\beta$ 溶 血性連鎖球菌による感染症が届け出対象となってい る. 年次別の報告数は 2011 年より増加傾向であり, そ れまで100例/年前後であった報告例が，2015年には第 


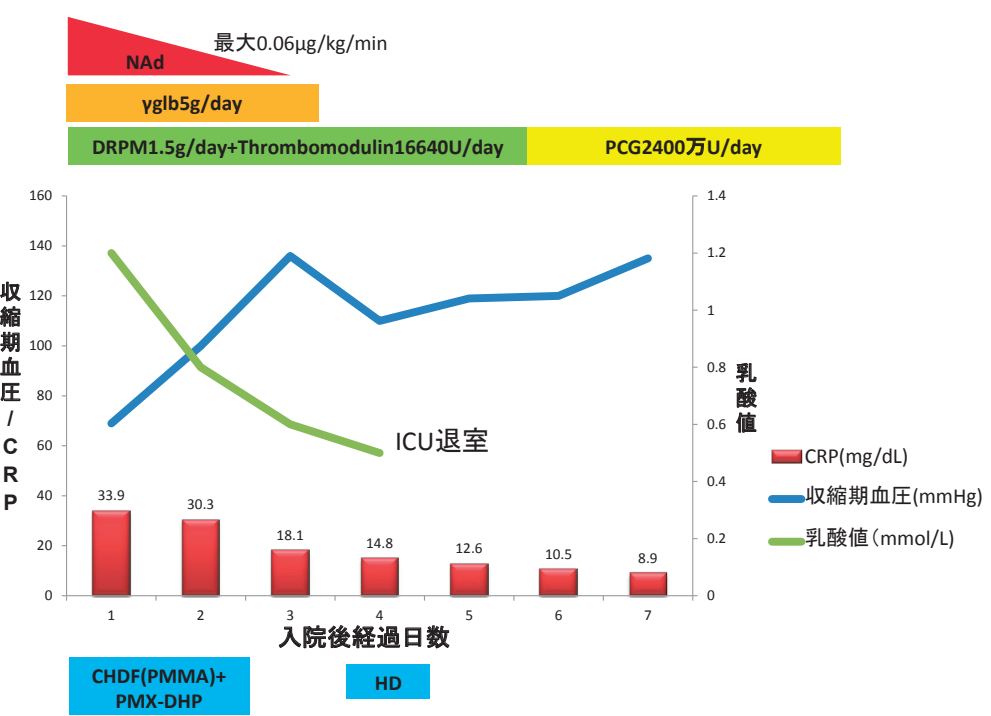

Fig. 2 入院後経過

Table 1 原発性腹膜炎で発症した STSS の本邦報告例

\begin{tabular}{|c|c|c|c|c|c|c|c|c|}
\hline 報告年 & 著者 & 年齢/性 & 入院時診断 & 培盖結果 & 感染経路 & 根本治療 & 補助治療 & 転帰 \\
\hline 2003 & 今村 & $54 / \mathrm{F}$ & 消化管穿孔 & 腹水 + & 腸管 & 開腹洗浄ドレナージ & PMX-DHP（2 回） & 生存 \\
\hline 2003 & 鶴田 & $38 / \mathrm{F}$ & 消化管穿孔 & 腹水 + , 血液 + , 腔 + & 膣 & 開腹洗浄ドレナージ & 不明 & 生存 \\
\hline 2004 & 堀江 & $67 / \mathrm{F}$ & 沉発性腹膜炎 & 腹水 - , 血液 + , 咽頭 + & 咽頭 & 開腹洗浄ドレナージ & PMX-DHP（2 回） & 死亡 \\
\hline 2004 & Kanetake & $40 / \mathrm{M}$ & 消化管穿孔 & 腹水 + , 血液 - , 咽頭 - & 咽頭 & 開腹洗浄ドレナージ & $\mathrm{CHDF}$ & 生存 \\
\hline 2010 & 星野 & $50 / \mathrm{M}$ & 沉発性腹膜炎 & 腹水 + & 不明 & 腹腔鏡 $\rightarrow$ 開腹 & PMX-DHP, CHDF, $\quad \gamma \mathrm{glb}$ & 生存 \\
\hline 2012 & 久田 & $35 / \mathrm{F}$ & 骨盤腹膜炎 & 腹水 + , 血液 - , 腔 - & 腔 & 保存 経皮ドレナージ & $\mathrm{CHDF}$ & 生存 \\
\hline 2013 & 田中 & $70 / \mathrm{M}$ & 細菌性肺炎/AKI & 胸水 + , 血液 + , 痰 + & 不明 & 保存 & $\mathrm{CHDF}$ & 死亡 \\
\hline 2014 & 浦 & $39 / \mathrm{F}$ & 沉発性腹膜炎 & 腹水 + , 血液 + & 不明 & 開腹洗浄ドレナージ & PMX-DHP, CHDF, $\quad \gamma$ glb & 生存 \\
\hline 2015 & 池上 & $30 / \mathrm{F}$ & 沉発性腹膜炎 & 腹水 + , 血液 + , 腔 - & 不明 & 開腹洗浄ドレナージ & 不明 & 生存 \\
\hline 2015 & 松田 & $58 / \mathrm{F}$ & 沉発性腹膜炎 & 腹水 + , 血液 - , 胵 + & 膣 & 開腹洗浄ドレナージ & $\mathrm{CHDF}$ & 死亡 \\
\hline 2016 & 松吉 & $58 / \mathrm{F}$ & 沉発性腹膜炎 & 腹水 + , 血液 + , 腔 - , 咽頭 - & 不明 & 開腹洗浄ドレナージ & $\mathrm{CHDF}$ & 生存 \\
\hline 2017 & 蓮井 & $50 / \mathrm{F}$ & 沉発性腹膜炎 & 腹水 + , 血液 + , 膣 + , 咽頭 - & 膣 & 開腹洗浄ドレナージ & 不明 & 生存 \\
\hline 2018 & 自験例 & $39 / \mathrm{F}$ & 沉発性腹膜炎 & 血液 + , 咽頭 - , 便 - & 不明 & 保存 & PMX-DHP, CHDF, $\gamma$ glb & 生存 \\
\hline
\end{tabular}

蓮井らの報告 Table 16)を一部引用, 改変. $\mathrm{M}:$ male, F : female, CHDF : continuous hemodiafiltration, $\gamma$ glb : ガンマグロブリン

24週の時点で既に204例報告されている4)。これは疾 患概念の定着とともに認知度が高まっているものと考 えられる。原発性腹膜炎は，STSSが呈する症状全体 のうち $1 \%$ を占めていると推測されており, 胵からの 上行性感染や咽頭炎, 筋膜炎からの血行性播種が感染 経路として推測されている5゙が，不明のまま治療され ていることも多い．医学中央雑誌（1987年から2017年 12月）にて「溶連菌」および「腹膜炎」をキーワード として検索し, さらにその論文を詳細に検討した結果,
原発性腹膜炎を呈したSTSSの症例は12例であり，自 験例を加えた13例について臨床的特徵を検討した (Table 1) 1337)815) 19)222). 本邦ではSTSSが1992年に清 水らにより初めて報告されて以来，これまで 1,700 例

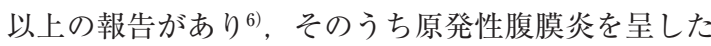
STSS は全体の $1 \%$ にも満たず，極めて稀な病態であ る。過去の報告例では死亡例で保存的加療の報告はあ るものの ${ }^{7}$, 保存的治療のみで救命しえた報告は自験 例以外に認めなかった。平均年齢は48.3歳（30７0歳） 
で 8 例 $(61.5 \%)$ と比較的若年発症が多く, 男女比は $3: 10$ で女性に多かった. 感染経路は咽頭が 2 例, 腸 管が 1 例, 腔が 4 例, 自験例を含めて不明が 6 例であ った. 血液培養は 8 例 $(61.5 \%)$, 腹水培養は 11 例 $(84.6$ \%) で陽性であった。 13例すべてにおいて，いずれか の検体から陽性所見が得られており, 原発性腹膜炎疑 診例における両検査の診断的意義は大きいと考える. 治療は11例 $(84.6 \%)$ で外科的ドレナージを施行され ており，うち10例 $(90.9 \%)$ で開腹洗浄ドレナージ, 1 例で経皮的穿刺ドレナージが行われていた．過去の 報告では, 早期の外科的ドレナージの重要性が示唆さ れている8). また, 補助治療として 5 例 $(38.4 \%)$ で PMX-DHPが施行され， 8 例 $(61.5 \%)$ でCHDFが施 行されていた. 自験例を含め, 3 例ではPMX-DHP と CHDFの両者が併用されていた，CHDFの施行率 の高さは, STSSの合併症に急性腎不全が多い4)こと に起因していると考えられる.死亡例は 3 例であるが, いずれも高齢者や基礎疾患を有する患者であり， STSS の死亡率が約 $35 \%$ 程度であることを考えると， 若年者ではより良好な予後が期待される.

STSSの発生機序として, 黄色ブドウ球菌と同様, 1スーパー抗原 (TSST-1) の関与が推測されている ${ }^{9}$. GASのスーパー抗原として, streptococcal pyrogenic exotoxin A (SpeA), SpeC, およびSSAなどの計14 種類が報告されており，これらによって多量のサイト カインが発生し体内の免疫系が覺乱され, 多様な臨床 症状を呈するとともにショック状態へ進行してい く3)21). これに血管透過性の亢進が加わることで腹腔 内へ大量の菌体が移動し多臓器への移行性が高まり, 負のスパイラルで病態が増悪していくと考えらえる. 自験例では, ICU入室当初より, PMMA膜を用いた CHDFと PMX-DHP を直列回路で併用した。 PMXDHPにはサイトカインCD14, CD16抗原陽性単球を 吸着させることにより炎症性サイトカインである IL-6, IL-8を低下させ, サイトカインバランスを安定 化させる効果があると考えられている ${ }^{3)}$. さらに, 単 球系細胞から放出される anandamide (ANA) と血小 板から 2-arachidonoyl glycerol (2-AG) といった内 因性カンナビノイドが放出されることでショックを惹 起することが判明しており, PMX-DHPはこの内因 性カンナビノイドや活性化好中球の吸着効果があるた め, 敗血症性ショックの生体内循環の正常化をもたら すと考えられている ${ }^{310)}$. 入院時当初, 身体所見と CT 所見から重症腸炎によるエンドトキシンショックを否
定できなかったためPMX-DHPを使用開始している が，のちに判明した結果でエンドトキシンは陰性であ り, Gram陰性桿菌も検出されなかった. しかし, PMMA膜には内因性カンナビノイドの吸着・除去能 があり ${ }^{1120)}$, 直列回路で 2 段階的にCHDFと PMXDHPを使用したことでサイトカイン吸着能がさらに 高まるといった相加・相乗効果が期待できるとの報告

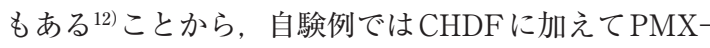
DHPを併用した。その後速やかに血圧の上昇とCRP の低下が得られ，翌日には循環動態は安定して昇圧剤 投与を終了できたため, 結果として両者の併用が有効 であった可能性がある。 また，ガンマグロブリンの使 用も, GASによって放出される外毒素の中和抗体と して働き有効との見解もある ${ }^{13)}$. 敗血症性ショックの 治療としては, 適切な輸液管理と早期の抗菌薬加療の 開始, lactateを指標とした循環動態の管理, 目標值 をICU入室後 3 時間以内に達成する 3hour-bundle な どが提唱されており ${ }^{14)}$ ，自験例でもこれらガイドライ ンに基づいた管理を行った.

本疾患における治療の問題点は「診断の困難さ」に ある122). 腹水を伴う急性腹症において, CTなど画像 診断で明らかな責任病変を認めない場合に原発性腹膜 炎を疑うとされている5 が，特異的な所見にそしいた め診断の確定は困難である. 自験例でも腹水が少量で あり検体は採取できなかったが，身体所見と血液培養 結果からSTSSによる原発性腹膜炎と診断した。本邦 の報告例では原発性腹膜炎を発症したSTSS13例のう ち，11例で外科的ドレナージ術が施行されており，そ のいずれも菌体量の減量による効果が推測されている が, 稀有な疾患であることもあり, 治癒機転について 一定の知見は得られていないのが現状である.今回の われわれの経験から, (1)腹水が少量で腹腔内に存在す る菌体の絶対量が少ない, (2)身体末梢循環不全の所見 が軽度で, SOFAスコアも軽症, (3)基礎疾患のない若 年発症などの症例おいては, 保存的治療により手術侵 襲が回避できる可能性が示唆された. 外科的な洗浄お よびドレナージが救命に必須であるとの考察も散見さ れる6)8) が，過去の報告でも当初は保存的治療を開始 した症例も存在しており, これらの症例が外科的治療 なしに救命しえたかは不明である。今後はICU管理 をはじめとした集学的治療の進歩により，上記のよう な患者背景に応じた保存的治療も選択肢の一つとなり 得ると考えられ，更なる症例の集積と治療方針の検討 が望まれる。 


\section{結語}

原発性腹膜炎で発症したSTSSで保存的に救命しえ た症例を経験した。過去の報告では外科的治療は不可 避とされてきたが, 保存的治療のみでも救命し得る症 例は存在するため, 慎重な手術適応の判断が望まれる.

なお, 本稿の要旨は, 第80回日本臨床外科学会総会 （2018年11月，東京）で報告した。

利益相反：なし

\section{文献}

1）星野伸晃, 長谷川洋, 坂本英至他：A群溶連菌に よる原発性腹膜炎の 2 例. 日腹部救急医会誌 $2010 ; 30: 697-701$

2) 松吉健夫, 今村剛朗, 佐々木庸郎他 : 原発性腹膜 炎を呈した劇症型 $\mathrm{A}$ 群溶連菌感染症の 1 例. 日 集中医誌 $2016 ; 23: 61-62$

3) 今村 秀, 安蘇正和, 三井信介他：原発性腹膜炎 にて発症した劇症型 $\mathrm{A}$ 群溶連菌感染症の 1 例. 日 臨外会誌 $2003 ; 64: 2879-2882$

4) 厚生労働省/国立感染症研究所感染症疫学セン夕 一：わが国における劇症型溶血性レンサ球菌感染 症の疫学. IASR $2015 ; 36: 153-154$

5) Westwood DA, Roberts RH : Management of primary group A streptococcal peritonitis : a systematic review. Surg Infect $2013 ; 14: 171$ 176

6）蓮井宣宏, 清水篤志, 麻生喜祥他: A 群溶連菌に よる原発性腹膜炎の 2 例. 日臨外会誌 2017 ; $78: 1904-1910$

7）田中宏典, 正久康彦, 石井祥裕他：原発性腹膜炎 と膿胸を伴った劇症型 $\mathrm{A}$ 群溶血性連鎖球菌感染 症の 1 例. 日救急医会誌 $2013 ; 24: 357-362$

8) 浦 勝郎, 三浦 巧, 小西和哉他 : インフルエン ザ感染後に腹膜炎で発症した劇症型 $\mathrm{A}$ 群溶連菌 感染症の 1 例. 日臨外会誌 $2014 ; 75: 2382-$ 2387

9) 内山武彦：細菌性スーパー抗原と感染症. Mod Media $1997 ; 43: 312-321$

10）船橋嘉夫, 永田啓史, 小林アズサ他：非グラム陰 性桿菌感染症による敗血症性ショックに対し PMX-DHPを施行した 2 症例の検討. エンドト キシン血症治療研会誌 $2015 ; 19: 59-60$

11）阪本雄一郎, 益子邦洋, 小幡 徹他: 内因性カン ナビノイド $(\mathrm{AEA}, 2 \mathrm{AG})$ 等の敗血症関連因子
から見た敗血症性ショック症例に対するPMMA$\mathrm{CHDF}$ の有用性に関する検討. ICU と CCU 2009 ; $33: 10-12$

12）神宮宏臣, 野口誉史, 新井よしみ他：G群溶連菌 による敗血症性ショックに対してPMX+SepXiris ${ }^{\mathbb{R}}$ CHDF および超低効率血液濾過透析（SPLED-f） が有効であった 1 例. 日血浄化技会誌 2017 ; $25: 74-76$

13) Darenberg J, Ihendyane N, Sjolin J, et al : Intravenous immunoglobulin $\mathrm{G}$ therapy in streptococcal toxic shock syndrome : a European randomized, double-blind, placebo-controlled trial. Clin Infect Dis $2003 ; 37: 333-340$

14) Seymour CW, Gesten F, Prescott HC, et al : Time to Treatment and Mortality during Mandated Emergency Care for Sepsis. N Engl J Med $2017 ; 376: 2235-2244$

15）鶴田宏史, 福井道彦, 小尾口邦彦他 : 原発性腹膜 炎にて発症した劇症型 $\mathrm{A}$ 群連鎖球菌感染症の 1 症例. 日集中医誌 $2003 ; 10: 213-214$

16）堀江 徹, 高木和俊, 永田 仁他: 腹膜刺激症状 を呈した劇症型 $\mathrm{A}$ 群溶血性連鎖球菌感染症の 1 例. 日臨外会誌 $2004 ; 65: 3125-3128$

17) Kanetake K, Hayashi M, Hino A, et al : Primary peritonitis associated with streptococcal toxic shock-like syndrome : report of a case. Surg Today $2004 ; 34: 1053-1056$

18）池上 淳, 沼田雅裕, 坂本育子他: 若年健康女性 に発症した劇症型 $\mathrm{A}$ 群溶連菌感染症による原発 性腹膜炎の 1 例。産と婦 $2015 ; 82: 697-701$

19）久田将之, 河北英明, 石崎哲央他 : 劇症型 $\mathrm{A}$ 群溶 連菌感染症（TSLS）を呈した骨盤腹膜炎の 1 例. 日外科系連会誌 $2012 ; 37: 869-875$

20）松村洋輔, 織田成人, 貞広智仁他 : 劇症型 $\mathrm{A}$ 群溶 血性連鎖球菌感染症に対し, ポリメチルメタクリ レート膜血液滤過器を用いた持続的血液滤過透析 を 2 系列同時施行した特発性細菌性腹膜炎の 1 救 命例. 日集中医誌 $2010 ; 17: 505-512$

21）川端重忠, 寺尾 豊: 劇症型 $\mathrm{A}$ 群レンサ球菌感染 症 (劇症化の分子機構). BIO Clin 2007; 22:39 $-44$

22）松田真輝, 澤野 誠, 大河原健人：骨盤内炎症性 疾患を呈した劇症型 $\mathrm{A}$ 群溶血性連鎖球菌感染症. 日腹部救急医会誌 $2015 ; 35: 321-323$ 


\title{
PRIMARY STREPTOCOCCAL PERITONITIS TREATED CONSERVATIVELY-A CASE REPORT-
}

\author{
Kohei IWASHITA, Atsuo KOBAYASHI, Atsushi TAKADA and Masaki KAWAHARA \\ Department of Surgery, Kanto Central Hospital
}

A 39-year-old woman visited our hospital with abdominal pain, fever, and diarrhea. Physical examination showed signs of peritoneal irritation, and laboratory findings indicated systemic inflammation, leading to a diagnosis of acute generalized peritonitis. Computed tomography indicated no signs of gastrointestinal perforation or intestinal ischemia to explain the patient's symptoms, and primary peritonitis was suspected. She received intensive care with circulatory and respiratory management, broad-spectrum antibiotics, catecholamines, continuous hemodiafiltration, and endotoxin adsorption therapy. Blood culture performed on day 4 revealed Group A Streptococcus pyogenes, and we diagnosed primary peritonitis secondary to streptococcal toxic shock syndrome. The aforementioned conservative treatment was continued, and she was closely monitored while we contemplated surgical treatment. Systemic symptoms subsequently improved, and the patient was discharged on day 23. Primary peritonitis secondary to Streptococcal toxic shock syndrome is rare, and in most cases, laparotomy is performed for drainage. Few reports have described life-saving conservative treatment in such patients. We report a case of primary streptococcal peritonitis that responded to conservative treatment.

Key words : STSS, primary peritonitis, conservative treatment 